\title{
Retratos de mortos e desaparecidos pela ditadura civil-militar brasileira e argentina ${ }^{1}$
}

\author{
Portraits of dead and missing by Brazilian and Argentine civil-military \\ dictatorship
}

\author{
Retratos de muertos y desaparecidos por la dictadura civil-militar \\ brasileña y argentina
}

\author{
Katia Helena Rodrigues Dias ${ }^{2}$ \\ Francisca Ferreira Michelon ${ }^{3}$
}

\begin{abstract}
Resumo
As ditaduras civis-militares surgidas na América Latina a partir da segunda metade do século XX tiveram como características comuns um autoritarismo repressivo contra seus opositores políticos ou qualquer pessoa que apresentasse ideologia diversa à ditadura e tudo o que ela representava. Como consequência, o governo militar de países como Brasil (1964 - 1985) e Argentina (1976 - 1983) estabeleceu sua base na Doutrina de Segurança Nacional, que tinha como objetivo inibir focos de resistência ao regime militar, justificado na ameaça do comunismo vigente na época. Nesse contexto, criou-se um estado de terror generalizado na população, o terror proveniente do Estado, conhecido também como Terrorismo de Estado. Nessa situação, muitas pessoas consideradas subversivas ou inimigas da nação por discordarem ou lutarem contra a tomada de poder foram presas, torturadas, mortas e desaparecidas. Nesse contexto, o presente estudo versa sobre os usos dos retratos de mortos e desaparecidos, a partir do processo de transição política (redemocratização) brasileira e argentina e tem como objetivo desenvolver uma análise comparada a partir da implementação de políticas públicas voltadas às memórias das vítimas e relacioná-las com os usos atribuídos a esses retratos a partir da consolidação de políticas de memória em cada país. Entre as diversas formas de implementação dessas políticas, a criação de Espaços e Instituições de Memória voltadas à memória da repressão são uma das formas de reparação simbólica em homenagem às vítimas. Nesse sentido, serão considerados casos analisáveis as fotografias expostas em caráter permanente nas instituições de memória representativas dessa temática em cada país: Memorial da Resistência (Brasil) e Espaço de Memória e Direitos Humanos - ESMA (Argentina).
\end{abstract}

Palavras-chave: retratos de mortos e desaparecidos, políticas de memória, ditadura civil-militar, Brasil, Argentina.

\begin{abstract}
The civil-military dictatorships arising in Latin America acts fron the second half of the 20th century had as common characteristics a repressive authoritarianism against their political opponents or any person due sepresaltasse ideology different to the dictatorship and everything it represented. As a consequence, the military government of countries such as Brazil (1964-1985) and Argentina (1976 - 1983) established it base in the National Security Doctrine, aimed at inhibiting outbreaks os resistance to the military regime, justified by the threat of communism prevailing at the time. In this context, a widespread state of terror was created in the population, state terro, also known as State Terrorism. In this situation, many people considered subversive or

\footnotetext{
${ }^{1}$ Este artigo resulta de um estágio doutoral realizado através do Programa Centros Associados para o Fortalecimento da Pós-Graduação Brasil-Argentina com convênio entre a Universidade Federal de Pelotas (UFPel) e a Universidade de Buenos Aires (UBA) o qual contou com o apoio da Coordenação de Aperfeiçoamento de Pessoal de Nível Superior (CAPES).

${ }^{2}$ Doutoranda em Memória Social e Patrimônio Cultural; UFPEL; Pelotas; RS; Brasil; dias.k.helena@ gmail.com

${ }^{3}$ Doutora em História pela Pontifícia Universidade Católica do Rio Grande do Sul; Porto Alegre. Doutora em Memória Social e Patrimônio Cultural; UFPEL; Pelotas; RS; Brasil; fmichelon.ufpel@gmail.com
} 
enemy of the nation for disagreeing or fighting the saizure of power were arrested, tortured, killed and missing. In the context, the present study deals with the uses of the dead and missing, from the processo of Brazilian and Argentine political transition (redemocratization) and aims to develop a comparative analysis from the implementation of public policies aimed at the memories of victims and relate them to the uses attributed to these portraits from the consolidation of memory policies in each country. Among the various ways of implementing these policies, the creation of Memory Spaces and Institutions focused on the memory of repression is one of the symbolic reparations in honor of the victims. In this sense, the analysis will be considered as permanent photographs in the representative memory institutions of this in each country: Memorial da Resistencia (Brazil) and Space of memory and Human Rights - ESMA (Argentina).

Keyword: portraits of the dead and missing, memory politics, civil-military dictatorship, Brazil, Argentina.

\section{Resumen}

Las dictaduras civil-militares que surgieron en América Latina a partir de la segunda mitad del siglo XX, tenían como características comunes un autoritarismo represivo contra sus oponentes políticos o cualquiera persona que presentara una ideología diferente de la dictadura y todo lo que representaba. Como consecuencia, el gobierno militar de países como Brasil (1964 - 1985) y Argentina (1976 - 1983) estableció su base en la Doctrina de Seguridad Nacional, destinado a inhibir focos de resistencia al régimen militar, justificado por la amenaza del comunismo prevaleciente en ese momento. En este contexto, se creó un estado generalizado de terror en la población, el terror que viene del estado, también conocido como terrorismo de estado. En esta situación, muchas personas consideradas subversivas o enemigas de la nación por estar en desacuerdo o luchar contra la toma del poder fueron arrestadas, torturadas, asesinadas y desaparecidas. Desde este contexto, el presente estudio aborda los usos de los retratos de los muertos y desaparecidos, del proceso de transición política (redemocratización) brasileña y argentina y con el objetivo de desarrollar un análisis comparativo a partir de la implementación de políticas públicas dirigidas a los recuerdos de las víctimas y relacionarlas con los usos atribuidos a estos retratos a partir de la consolidación de estas políticas de memoria en cada país. Entre las diversas formas de implementar estas Políticas de Memoria, la creación de Espacios de Memoria e Instituciones enfocadas en la memoria de la represión, son una de las reparaciones simbólicas homenaje a las víctimas. En este sentido, consideraremos, como casos analizables, fotografías exhibidas permanentemente en instituciones de memoria representativas de este tema en cada país: Memorial de la Resistencia (Brasil) y Espacio de Memoria y Derechos Humanos - ESMA (Argentina).

Palabras clave: retratos muertos y desaparecidos, políticas de memoria, dictadura civil-militar, Brasil, Argentina

\section{Introdução}

A ditadura civil militar na América Latina teve, de modo geral, uma trajetória inicial similar, impulsionada pelo contexto mundial da Guerra Fria; o mundo de então estava dividido entre dois tipos de ideologias político-econômicos, o capitalismo, sob influência dos Estados Unidos da América e o socialismo, sob influência da União Soviética. Tanto no Brasil (1964-1985) quanto na Argentina (1976-1983), nos casos analisados pelo presente artigo, os militares estavam taticamente preparados e amparados pela elite social local, conforme indica Dreifuss (1987), e também pelos Estados Unidos, para aniquilar a vertente comunista que naqueles anos representavam alguma ameaça ao poderio capitalista sob a égide norte-americana.

O regime político ditatorial instaurado nesses países derrubou os presidentes legitimamente eleitos, perseguiram seus apoiadores e todo e qualquer cidadão que discordasse 
da nova ordem imposta. Amparado pela Doutrina de Segurança Nacional (DSN), cujo lema era "Segurança para o Desenvolvimento", o que justificou, em nome da defesa nacional, a centralização do poder, a retirada dos direitos políticos e de livre expressão da sociedade, a militarização do Estado e as consequentes ações provenientes dessa nova ordem, tais como: perseguições, prisões, torturas, mortes e desaparecimentos. De acordo com Padrós (2012), “as Forças Armadas se auto-perceberam como fator fundamental da 'construção nacional', com a consequente tendência de intervir nos mais diversos âmbitos da vida social para impor sua lógica securitista" (p. 499).

Importante salientar que para tanto era necessário haver um convencimento da população em geral, corroborando a ideia de que tais medidas eram necessárias para o bem maior da nação. Assim, houve uma forte campanha para "influenciar e manipular a população, mediante o controle da informação, da educação e da cultura, entre outros, confluindo na construção de um discurso legitimador da implantação e continuidade do novo regime" (PADRÓS, 2012, p. 513). E, com as bênçãos da população civil em geral, essas ditaduras se estruturaram, espalhando terror e medo entre seus opositores. A citação abaixo é elucidativa do exposto:

Como instrumento utilizado em larga escala, a "guerra psicológica" foi duplamente eficiente: demonizou a "subversão" aos olhos da população, e tentou captar simpatias para o Estado de exceção. Inúmeros fatos foram distorcidos para produzir o efeito esperado junto à sociedade - bloquear gestos de solidariedade e reações negativas diante da política repressiva -complementando iniciativas diversionistas e reforçando mentiras oficiais. Tudo isso feito para atemorizar os dissidentes e confundir e neutralizar os indecisos. (PADRÓS, 2012, p. 514)

A partir da segunda metade da década de 1970, os regimes políticos militares dos países da América Latina iniciaram um processo de desgaste e começaram a perder força e apoio das camadas da sociedade civil que inicialmente os apoiaram e, de certa forma, legitimaram os abusos cometidos em nome da defesa nacional. Cabe ressaltar que, conforme expõem Bertoncelo (2009) e Zaverucha (2010), o processo de decadência dos regimes ditatoriais coincidiu com uma conjuntura econômica mundial afetada pela crise do petróleo ${ }^{4}$, recessão, inflação e dívida externa, o que resultou em insatisfação generalizada. No início da década de 1980, as ditaduras civis-militares da Argentina (1983) e do Brasil (1985) chegaram ao final.

\footnotetext{
${ }^{4}$ A crise do petróleo (1973) foi reflexo da Guerra no Oriente Médio, os países árabes membros da Organização dos Países Exportadores de Petróleo (OPEP), detentores da maior parte da produção mundial, proclamaram embargo às Nações aliadas a Israel. Houve uma significativa redução na produção do petróleo, suspendeu-se as importaçães e depois elevou-se drasticamente o preço do produto, em 5 meses o aumento foi de $400 \%$, prejudicando as importações pelos países dependentes. Tal crise ocasionou reflexos nas potências ocidentais e afetou e desestabilizou a economia mundial.
} 
De modo geral, as linhas acima indicam as semelhanças na origem e consolidação desses regimes autoritários na América Latina. Apontam também, como consequência, o saldo traumático de violações de Direitos Humanos. Entretanto, no período posterior, o processo de abertura e transição política do regime, aconteceu de maneira diferente em cada país. O texto tem como ponto de partida o estudo comparativo entre Brasil e Argentina e preconizou relacionar a redemocratização desses países com ênfase na implementação de políticas de memória referente ao período autoritário e repressivo.

Conforme Jelin (2002), as políticas de memória são ativadas pelos “empreendedores de memórias" - indivíduos unidos em prol do reconhecimento e reparação pelo Estado, unindo o clamor popular como um forte apelo para legitimar pela esfera pública as medidas de reparação e, nesse sentido, a autora confere a significância dessas ações as quais "nunca suceden por azar, sino que es produto de la presencia de sujetos activos en un escenario político de lucha en el presente, un presente ligado a acontecimientos pasados" (Jelin, 2017, p. 264). Em consonância ao exposto, Michel (2010) a define como:

[...] conjunto de intervenções de atores públicos que objetivam produzir e impor lembranças comuns a uma dada sociedade, em favor do monopólio de instrumentos de ações públicas (comemorações oficiais, programas escolares de história, leis memoriais, panteões, etc.). A construção de uma narrativa coletiva feita pelos poderes públicos é parte integrante desse modo de ação pública. Essas narrativas se orientam a supostamente unir membros de uma sociedade ao redor de uma história comum, mesmo se essas configurações narrativas dizem mais sobre a maneira pela qual o poder se coloca em cena e seus valores do que propriamente sobre a memória coletiva sobre a qual supostamente se apoiaria. (MICHEL, 2010, p. 14-15) .

De acordo com Delgadillo (2015), as políticas de memória são um conjunto de medidas instrumentalizadas pelo Estado com o intuito de reparação às vítimas de um passado marcado por atos de violência. São políticas públicas voltadas à memória e implementadas pela ação do Estado, mas a demanda e formulação da agenda parte da articulação dos movimentos sociais. Nesse sentido, o autor aponta a importância dos atores socias como fator determinante para a consolidação dessas políticas e afirma o quão significativo é a formação da opinião pública como forma de fundamentação e manutenção das políticas de memória, assim as "organizaciones de la sociedad civil pueden incidir en las políticas públicas en la medida en que dispongan de ciertas capacidades como: capital político, capital económico, capital organizacional y capital simbólico”. (DELGADILLO, 2015, p. 55).

As políticas de memória, conforme Delagadillo (2015), referem-se à justiça e à reparação. No âmbito da justiça, intenciona-se saber a verdade e responsabilizar os culpados, papel desempenhado por Comissões da Verdade. As reparações podem ser de dois tipos: econômicas e simbólicas - a primeira, como uma forma de reparar com valores monetários as 
vítimas sobreviventes e a segunda, voltada a memórias das vítimas e familiares, podendo compreender, por exemplo, a criação de Instituições de Memória.

O contexto de redemocratização no Brasil e na Argentina foi alicerçado de forma diferente. O Brasil teve como característica uma transição lenta, gradual e segura que durou aproximadamente uma década e aconteceu de forma pactuada entre os mesmos setores que instauraram a ditadura. Esse tempo foi suficiente para estabelecer as bases da democracia, de acordo com os interesses do grupo político-econômico dominante. Assim, foi sancionada a Lei da Anistia ${ }^{5}$ que, conforme Gonçalves (2014), libertou os presos políticos e exilados, e conferiu a impunidade aos crimes políticos ou $\operatorname{conexos}^{6}$ cometidos durante aquele período, desse modo, os militares também não poderiam ser penalizados pelos crimes cometidos, assim a anistia ficou conhecida como anistia recíproca, a qual vigora até a atualidade.

$\mathrm{Na}$ Argentina, por outro lado, a transição ocorreu de forma mais abrupta, após a derrota na Guerra das Malvinas, o governo, que já se apresentava bastante desgastado, viu uma oportunidade de afirmar a sua força, caso conseguisse vencer a Inglaterra na disputa territorial pelas Ilhas Malvinas. Após o fracasso, o descrédito perante os diversos setores da sociedade civil só aumentou. Nessa conjuntura, os movimentos sociais em busca dos desaparecidos cresciam e ganhavam visibilidade internacional, assim, o governo militar em menos de um ano abriu processo eleitoral para eleições diretas. Entretanto, antes de sua retirada do poder, houve um comunicado em rede nacional denominado "Informe Final de la Junta Militar sobre la guerra contra la subversión" com objetivo de justificar os atos cometidos, houve também a promulgação da Lei da Pacificação Nacional ${ }^{7}$ com intuito de garantir impunidade aos crimes. Após a posse do novo presidente eleito, revogou-se tal lei e os julgamentos e prisões dos oficiais militares aconteceram no primeiro ano de governo democrático.

A consolidação dos regimes autoritários na América Latina, na segunda metade do século XX, aconteceu de maneira bastante semelhante. O contexto mundial e as suas diretrizes do autoritarismo repressivo tiveram a mesma origem, ideologia e práticas. Entretanto, no momento da distensão política tais regimes se diferenciaram e cada qual seguiu um caminho. De acordo com Jelin (2019), ao analisar esses processos em ambos os países, é possível observar em relação à Argentina a peculiaridade de haver "muita política [é] feita nas

\footnotetext{
${ }^{5}$ Decreto-Lei n ${ }^{\circ} 6.683 / 1979$

${ }^{6}$ Crimes conexos podem ser compreendidos a uma heterogeneidade de crimes cometidos em função daquele contexto político. Por exemplo, falsificar um documento e utilizar de falsidade ideológica para fugir da repressão e viver na clandestinidade e também cometer atos arbitrários e violentos pelos agentes de segurança do Estado.

${ }^{7}$ Lei no $22.924 / 1983$
} 
ruas” (JELIN, 2019, p. 10) e no Brasil, a discussão política é “ muito mais classista[s] no sentido de que somente as elites discutem, a sociedade menos" (JELIN, 2019, p. 10). Tais características, de modo geral, configuraram-se no contexto da redemocratização desses países.

Tendo como ponto de partida o contexto mencionado acima, o presente estudo teve como propósito desenvolver uma análise comparada entre os países supracitados, por meio dos recursos visuais específicos da linguagem fotográfica, abrangendo reflexões sobre memória social e memórias traumáticas. Nesse universo, considerou-se como campo de observação as fotografias das Instituições de Memória voltadas ao contexto dessas ditaduras; no caso do Brasil, o Memorial da Resistência e no da Argentina, o Espaço de Memória e Direitos Humanos.

\section{O Espaço de Memória e Direitos Humanos (Buenos Aires - Argentina)}

O local originalmente funcionara como uma Escola de Mecânica da Armada (ESMA), pertencente à Marinha, e durante a ditadura civil-militar argentina configurou-se como um dos Centros Clandestinos de Detenção, Tortura e Extermínio (CCDTeE). Por lá, estima-se que 5 000 mil pessoas estiveram em cativeiro, das quais apenas 100 sobreviveram.

Terminada a ditadura, esse e outros lugares foram reivindicados pelas organizações e movimentos sociais para que fossem transformados em lugares de memória, e assim, em 2004, o local foi ressignificado e passou a ser uma Instituição de Memória referente à ditadura. Abrangendo uma ampla área, ali estão presentes diversas instituições ligadas à preservação e promoção da memória desse passado recente da Argentina (museus, centro cultural, arquivo e diversas instituições governamentais e não governamentais relacionadas aos direitos humanos).

No discurso visual do local, há predominância dos retratos das pessoas que estiveram em cativeiro e estão desaparecidas. Esses retratos foram obtidos por um dos poucos sobreviventes do local, Victor Basterra $^{8}$, que conseguiu esconder cópias dos prisioneiros fichados. Esses retratos mostraram-se determinantes para saber o destino das pessoas que ali estiveram e nunca mais foram encontradas.

A expografia do Espaço de Memória e Direitos Humanos tem como principal elemento esses retratos, dispostos lado a lado em diferentes tamanhos e formatos e em todos

\footnotetext{
${ }^{8}$ Sobre Victor Basterra, ver artigo DIAS; MICHELON (2019), Revista Latino-Americana de Estudos em Cultura e Sociedade - RELACult. V. 05, ed. especial, artigo n 1085 , abr. 2019.
} 
os locais, painéis, muros e fachadas, janelas, entradas e corredores de prédios administrativos nos mais variados suportes.

Há, conforme observado, trabalho expográfico intenso, poético, reflexivo. Entre as exposições de caráter permanente no espaço externo comum, destaca-se aqui dois projetos de caráter contínuo: "Memorias de Vida y Militancia" e "Presente". Dispostos por toda extensão externa do local, sua expografia busca em certa medida recuperar as identidades roubadas.

O projeto "Presente" (figuras 1 e 2) é composto por um conjunto de ampliações fotográficas em tamanhos variados, fixadas nos muros e fachadas externas do espaço. A intervenção tem o propósito de trazer as marcas dessas ausências e propor um espaço de reflexão. As instalações são feitas junto aos familiares dos desaparecidos, gerando um espaço de encontro, escuta, emoção e significados. Expostas ao ar livre, periodicamente a intervenção acontece para substituir os retratos que com a ação do tempo vão desaparecendo.

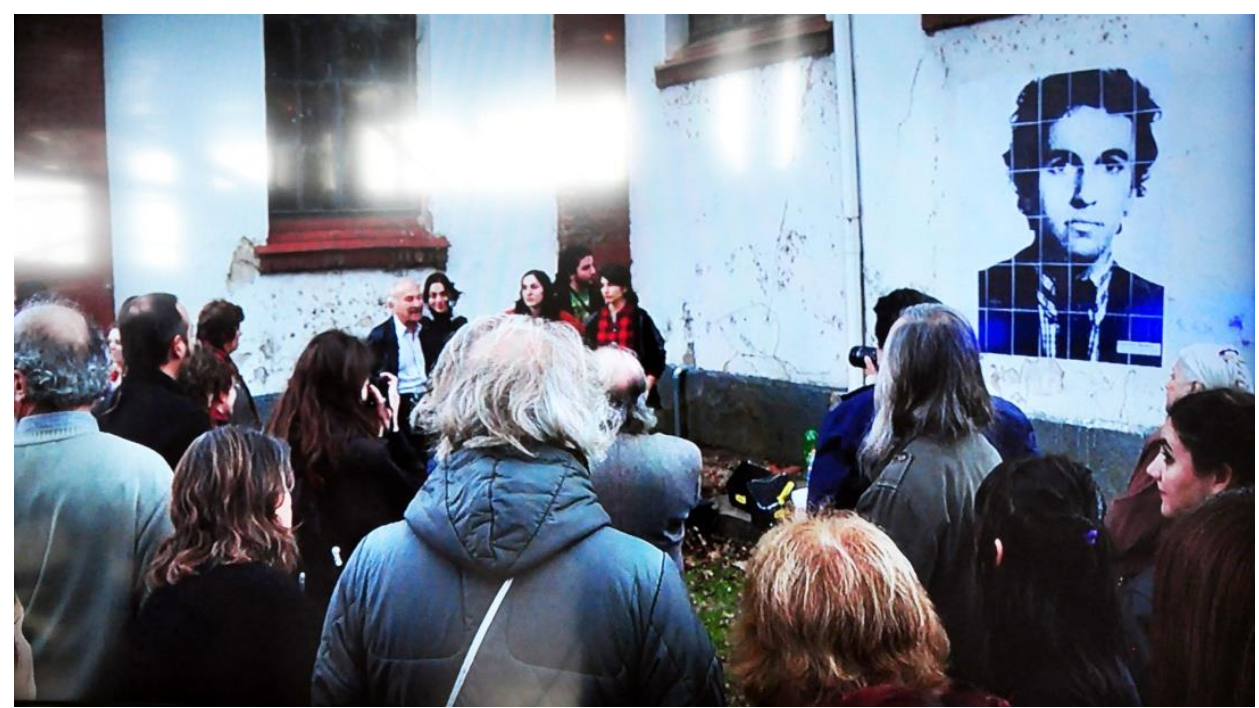

Figura 1 - Momento da Instalação do Projeto Presente. Fotografia da autora, 2017. 


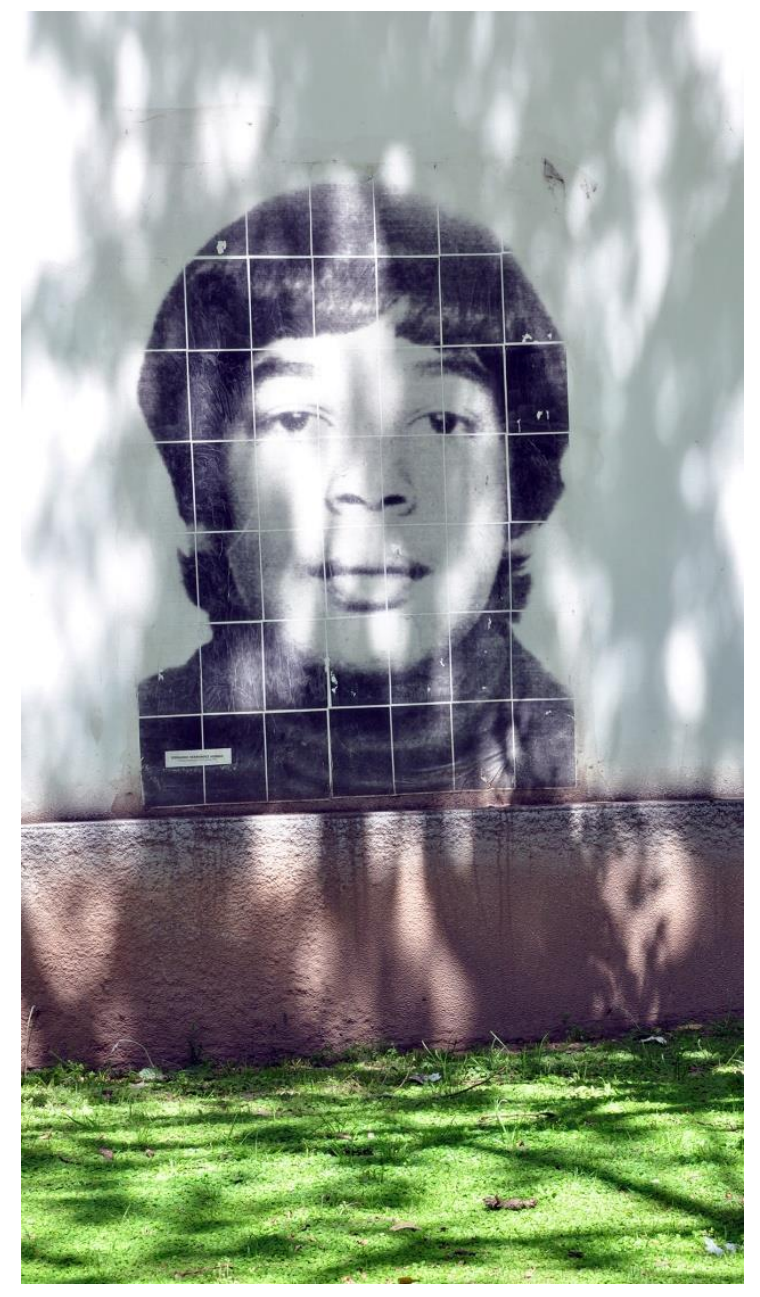

Figura 2 - Retrato do Projeto Presente. Fotografia da autora, 2017.

O projeto "Memorias de Vida y Militancia" (figuras 3 e 4) são painéis dispostos pelas ruas do espaço. Nesses painéis, há fotos retiradas de álbuns de família e um texto narrando a história de vida dessas pessoas. Produzidos também com ajuda dos familiares, por meio de entrevistas e seleção fotografias. Esse encontro oportuniza construir um discurso narrativo sobre as circunstâncias que levaram ao desaparecimento, preservando a identidade que o Estado ditatorial tentou apagar. Embora os destinos e vidas tenham sidos interrompidos, a imagem resistiu, graças à ação dos atores da sociedade civil. 
RELACult - Revista Latino-Americana de Estudos em Cultura e Sociedade

Revista Latinoamericana de Estudios en Cultura y Sociedad | Latin American Journal of Studies in Culture and Society V. 06, n⿳0 01, jan-abr., 2020, artigo n 1755 | claec.org/relacult |e-ISSN: 2525-7870

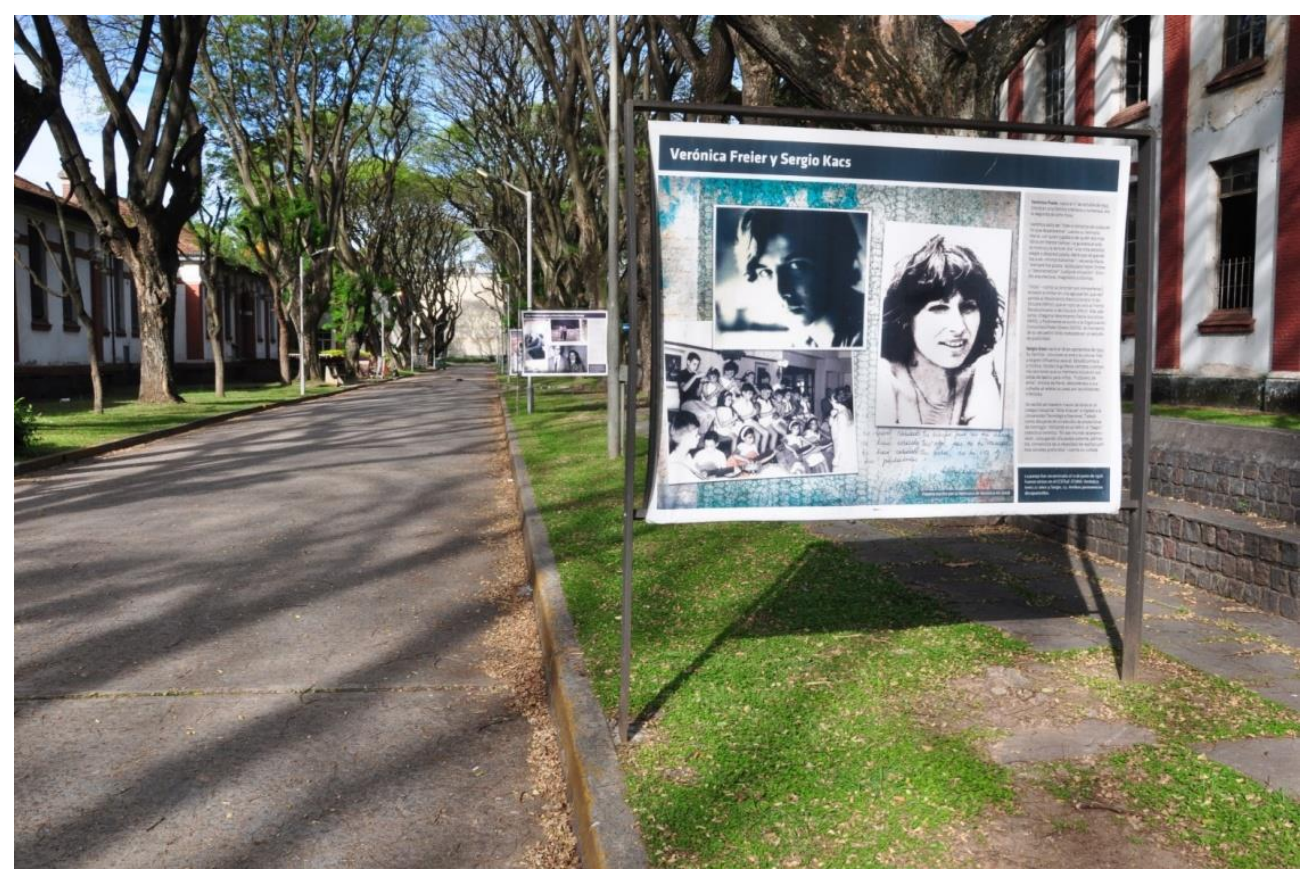

Figura 3 - Painéis do Projeto Memorias de Vida y Militancia. Fotografia da autora, 2017.

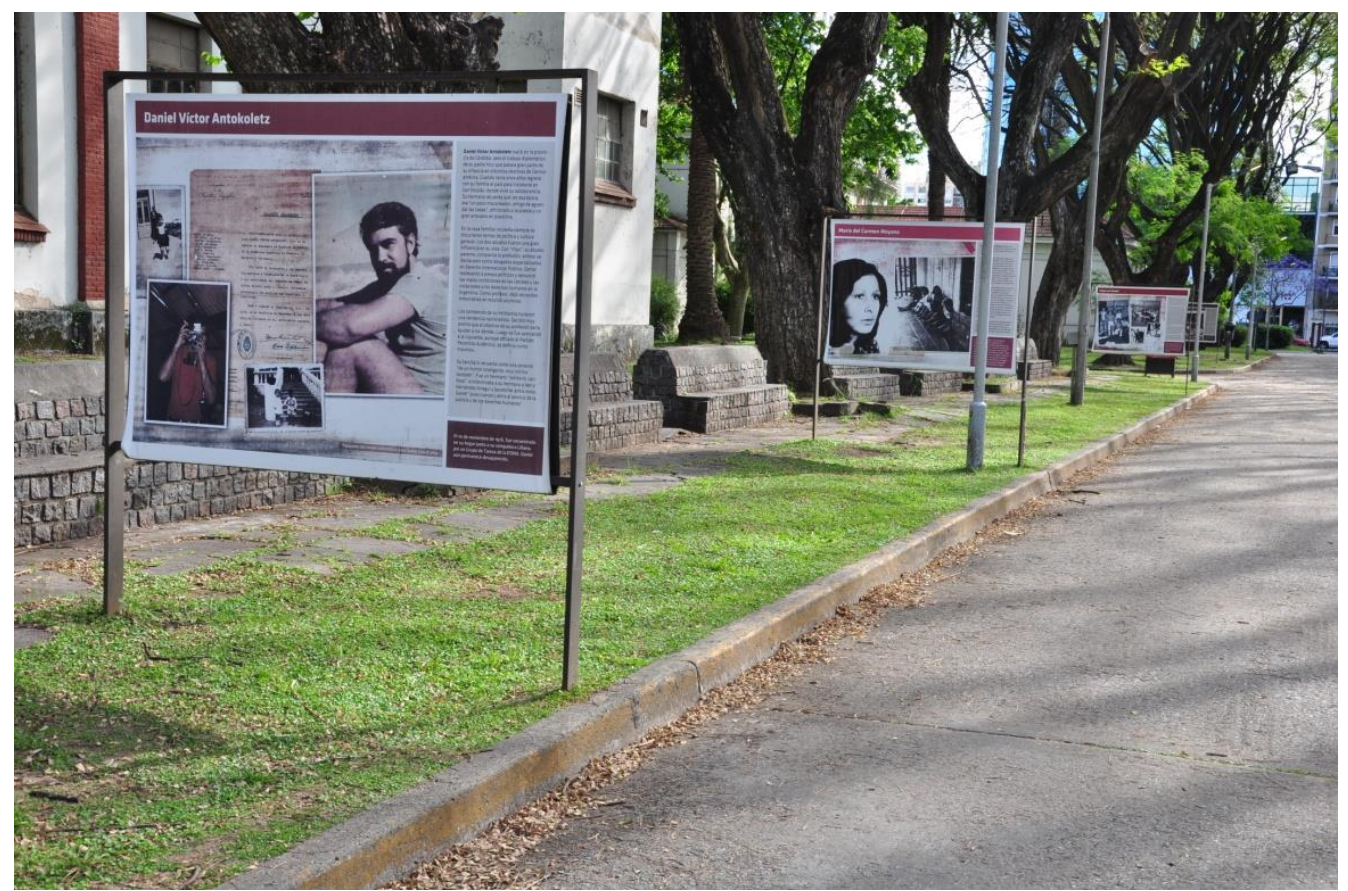

Figura 4 - Painéis do Projeto Memorias de Vida y Militancia. Fotografia da autora, 2017.

Os retratos de mortos e desaparecidos, conforme pontua Catela (2012), não tinham a intenção de "fazer história". Quando o contexto e a condição do indivíduo retratado se modificam, esses retratos são utilizados com outros propósitos. Originalmente produzidos para identificar o cidadão em um documento de identidade ou para compor os álbuns de família, no momento posterior são usados para denunciar o desaparecimento, assim 
adquirindo sentido oposto. Primeiramente, os retratos são utilizados para comprovar a existência e a vida do cidadão e depois é indicativo da ausência causada pelo desaparecimento ou morte.

\begin{abstract}
Esta conversão do uso da fotografia, que originalmente retratou um cidadão e, em seguida retrata o mesmo indivíduo como desaparecido, mostra-nos que para além da intenção de sua produção, o que interessa como dado etnográfico é o modo como passa informar sobre esta nova noção de pessoa que está desaparecida. Os diversos espectadores passam a lê-las e observá-las em seus novos contextos de significação, onde o que se dá é uma interpretação de uma transformação do real. (CATELA, 2012, p.114)
\end{abstract}

O discurso narrativo oportunizado por meios desses retratos são marcas do Espaço de Memória e Direitos Humanos. O uso intensificado e diversificado desses retratados tem o poder de sensibilização e, mesmo que o espectador não saiba o que de fato ocorreu, instiga a imaginação sobre o destino dessas pessoas e, dessa forma, a representação fotográfica ligada à violência de Estado se constitui em atos sociais. Nesse sentido, conforme Davallon (1992), esses espaços são fundamentais, conseguindo através dos recursos expográficos sensibilizar o público ao abranger as memórias traumáticas.

\title{
3.Memorial da Resistência (São Paulo - Brasil)
}

O local que hoje abriga o Memorial da Resistência, situado no centro de São Paulo, funcionou durante o período de 1940 a 1983 como Departamento Estadual de Ordem Política e Social (DEOPS), e, durante os anos da ditadura brasileira, o local serviu como presídio para onde os opositores políticos eram levados. Ali, conforme os testemunhos das vítimas sobreviventes, muitos sofreram torturas.

Foi inaugurado em janeiro de 2007, como uma medida de política pública do Estado de São Paulo, e com intenção de preservar as memórias da repressão política do Brasil Republicano. Assim o recorte dado à Instituição abrange desde 1889 até os dias atuais, embora a ênfase do lugar priorize o período da ditadura civil-militar. O espaço expositivo é divido em Exposições Temporárias e Exposições de Longa Duração. Para efeito dessa análise serão consideradas as exposições de caráter permanente, em que há o uso de retratos de mortos e desaparecidos. A expografia do Memorial da Resistência faz uso de fotografias como pano de fundo de grandes painéis informativos (figura 5). Tais painéis têm como propósito informar o que representou a ditadura e mostrar suas práticas repressivas dentro e fora das dependências do DEOPS e há também uma parte informativa sobre o processo de patrimonialização do prédio. A expografia está dividida em quatro módulos: a) O edifício e 
suas memórias; b) Controle, repressão e resistência: o tempo político da memória; c) A construção da memória: o cotidiano nas celas do DEOPS/SP; e d) Da carceragem ao Centro de Referência.

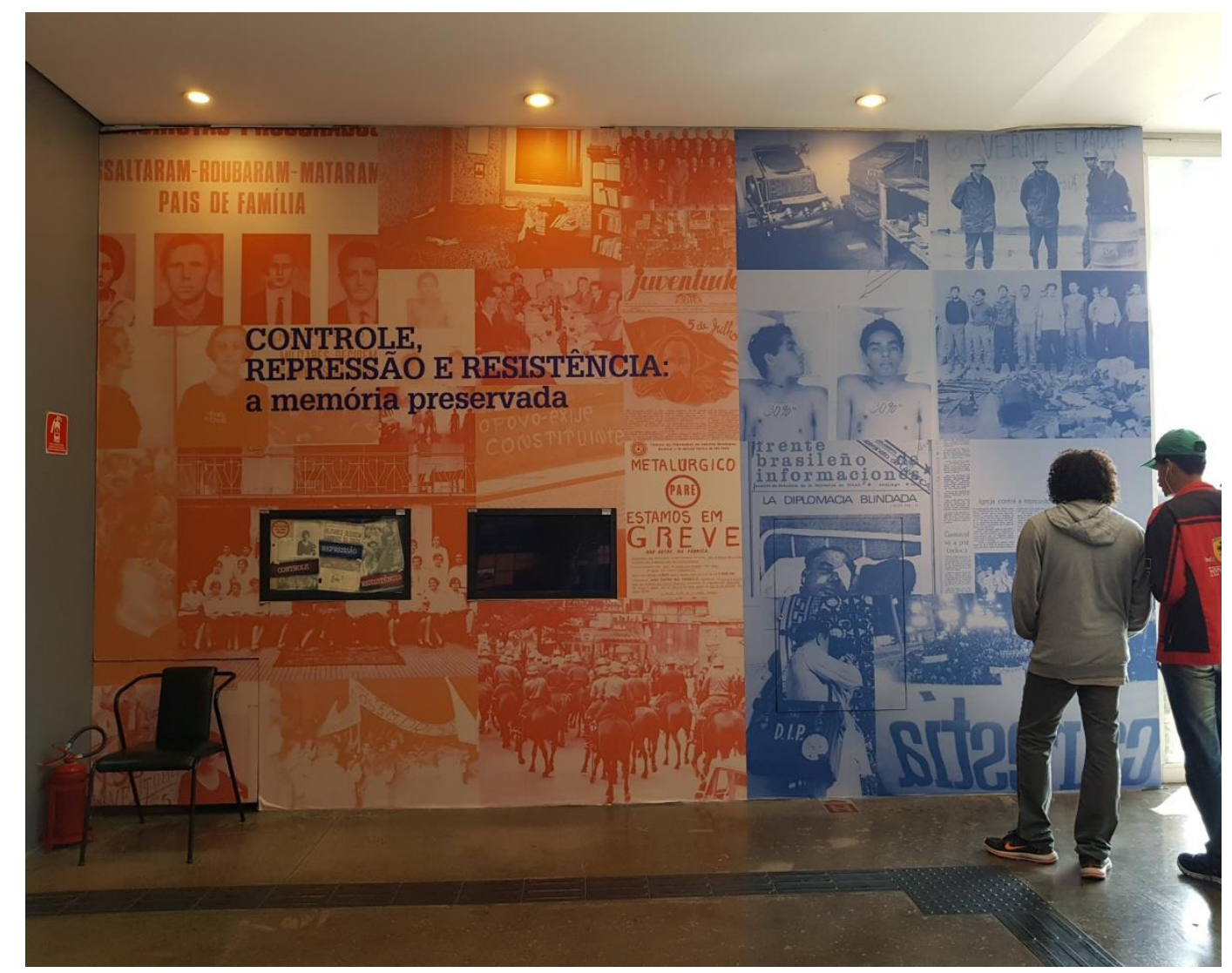

Figura 5 - Painel com fotografias Memorial da Resistência. Fotografia da autora, 2018.

Desses quatro módulos, o que apresenta mais especificamente o retrato é o módulo C: dentro de uma das celas onde ficavam os presos políticos, há uma projeção de retratos fotográficos de identificação documental de alguns dos prisioneiros que por ali passaram e foram fichados (figuras 6 e 7). A projeção dura aproximadamente 5 minutos e passa continuadamente. Os retratos se misturam com as imagens dos arquivos e fichas dos detentos, intercalando rostos e palavras que indicam o destino imposto a essas pessoas pelo regime autoritário e repressivo daquela época. 


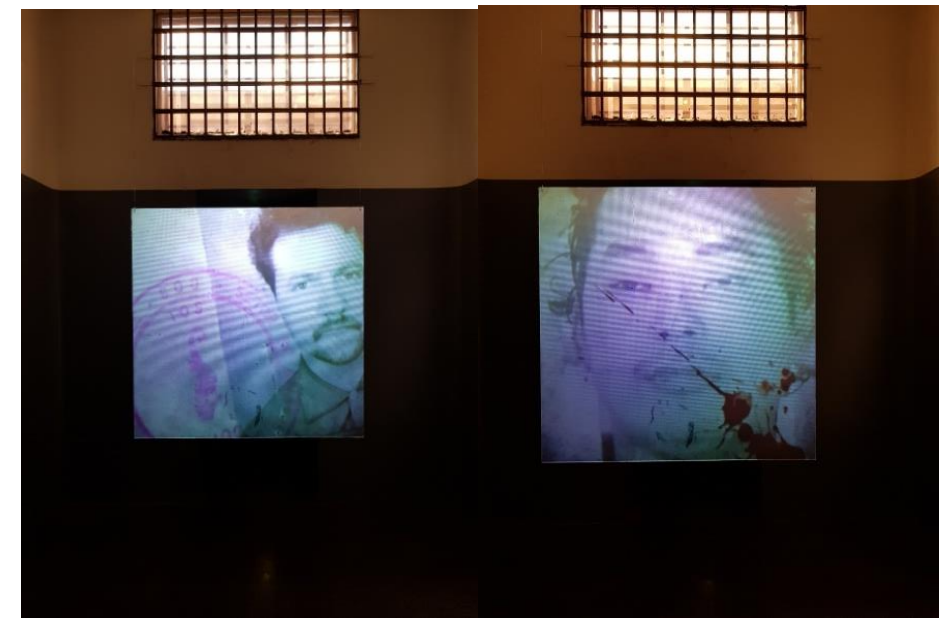

Figura 6 e 7 - Projeção com retratos. Memorial da Resistência. Fotografia da autora, 2018.

Ao entrar na cela, recriada para visitação, e ao observar os rostos das pessoas que ali estiveram, impossível não imaginar o que ali aconteceu, por mais incompreensível que tudo possa parecer. Imaginar o inimaginável com pontua Didi-Huberman (2004) em seu livro Imágenes pese a todo, no qual o autor analisa quatro fotografias obtidas dentro do campo de concentração do regime nazista. Essas imagens, de acordo com autor, indicam os atos desumanos, violentos e as mortes que ali ocorreram; fazem imaginar as circunstâncias desses atos. Os retratos apresentados no presente artigo, em ambas as Instituições de Memória analisadas, são indicativos do destino das pessoas. Assim, conforme o autor indica em sua obra posterior, "a imagem não é um simples corte praticado no mundo dos aspectos visíveis" (DIDI-HUBERMAN, 2012, p.207). Sua construção acontece no plano da imaginação "assim como não há forma sem formação, não há imagem sem imaginação" (DIDI-HUBERMAN, 2012, p. 208).

A reflexão de Didi-Huberbam leva a imaginar no potencial dessas imagens para o que não está registrado no suporte, e sim no que ela representa e no que se quer transmitir de acordo com os usos atribuídos a elas em outro contexto. A construção do imaginário sobre esses retratos está no tempo estendido e de acordo com as palavras do autor "son para nosotros tan preciosas porque nos ofrecen la imagen de lo humano pese a todo, la resistencia por la imagen - un pobre fragmento de película - a la destrucción de lo humano que, sin embargo, ella documenta" (DIDI-HUBERMAN, 2004, p.234). É nesse sentido que o autor confere a esse tipo de imagens a capacidade de fazer imaginar, apesar de tudo.

\section{Considerações Finais}

A violência política proveniente do Estado, nesses países, deixou marcas, conforme afirmaram Ferreira e Michelon (2015) "cicatrizes da memória" - na sociedade que podem ser 
vistas, sentidas, resssignificadas de diferentes formas, por intermédio de diferentes atores sociais. Dentre os meios conhecidos e mais utilizados para tratar de memória social, a fotografia tem, entre suas especificidades, o potencial inerente aos recursos visuais e apresenta-se como um eficaz suporte de memória. Em se tratando de memórias relacionadas a eventos traumáticos os quais violaram os direitos fundamentais do ser humano em esferas e graus gigantescos de abusos de poder e força, os usos dados à fotografia têm mostrado um significativo recurso reivindicatório de memória, verdade e justiça.

O ponto de partida para consolidação de regimes autoritários na América Latina a partir da segunda metade do século XX, não por acaso aconteceu de maneira semelhante. Regido pelo contexto mundial, as diretrizes que geriam o autoritarismo político que culminou em ditaduras civis-militares tinham a mesma origem, filosofia, metodologia prática e objetivos. Após os golpes consolidados, a trajetória alinhada num primeiro momento foi se desenhando de maneira singular em cada país.

A medida em que o regime militar se desgastava e perdia força, o retorno à democracia estava cada vez mais próximo. Entretanto, as formas e condições para que ela se consolidasse de fato foi conduzida de forma diferente. O término do regime ditatorial militar brasileiro e argentino, países analisados no texto, foi diferente e, portanto, o processo de transição (redemocratização) e a consolidação da democracia foi alicerçada, em cada país, sobre as bases estruturais consolidadas naquele momento.

\section{Referências}

BERTONCELO, Edison Ricardo Emiliano."Eu quero votar para presidente": uma análise sobre a Campanha das Diretas.Lua Nova, núm. 76, pp. 169-196 Centro de Estudos de Cultura Contemporânea São Paulo, Brasil. 2009.

CATELA, Ludmila da Silva. Todos temos um retrato: indivíduo, fotografia e memória no contexto do desaparecimento de pessoas. Revista TOPOI, Revista de História. Programa de Pós-Graduação em História Social da UFRJ vol.13, nº. 24, jan.-jun, Rio de Janeiro, pp. 111123, 2012. Disponível em: http://www.scielo.br/pdf/topoi/v13n24/1518-3319-topoi-13-2400111.pdf.

DAVALlON, J. "Le muséeest-ilvraimentun média? Publics et Musées". Em: Presses Universitaires de Lyon, 1992, $\mathrm{n}^{\mathrm{o}}$ 2: p. 99-123. Disponível em: http://www.persee.fr/doc/pumus_1164-5385_1992_num_2_1_1017. Data da última consulta: fevereiro, 2017.

DELGADILlO, Juan Mario Solís. Los tiempos de la memoria en las agendas políticas de Argentina y Chile. Buenos Aires: Eudeba, 2015. p. 25-77 
DIAS, Katia Helena Rodrigues. MICHELON, Francisca Ferreira. Retratos de desaparecidos no Espaço de Memória e Direitos Humanos/ESMA, Argentina. Revista Latino-Americana de Estudos em Cultura e Sociedade - RELACult. V. 05, ed. especial, artigo no 1085, abr. 2019. Disponível em: http://periodicos.claec.org/index.php/relacult/article/view/1085

DIDI-HUBERMAN, George. Imágenes pese a todo: Memoria Visual do Holocausto. Barcelona: Paidós Ibérica, 2004.

nov. 2012.

Quando as imagens tocam o real. Pós: Belo Horizonte, v.2 n.4, p. 204,

DREIFUSS, René. 1964: A conquista do estado. Rio de Janeiro: Vozes, 1987.

FERREIRA, Letícia. MICHELON, Francisca. Cicatrizes da Memória: fotografias de desaparecidos políticos em acervos de museus. In: Estudos Iberos-Americanos, Porto Alegre, v.41, $\mathrm{n}^{\mathrm{o}} .1$, jan./jun. p.79-97, 2015.

GONÇALVES, Danyelle Nilin. Os sentidos e as disputas em torno da anistia e da reparação de perseguidos políticos no Brasil. Entre a memória e o esquecimentos: estudos sobre os 50 anos do golpe civil-militar no Brasil. (org.) Carlos Artur Gallo; Silvania Rubert. Porto Alegre: Editora Deriva. pp. $211-224,2014$.

JELIN, Elizabeth. Los trabajos de la memoria. Madrid, Siglo XXI de España Editores, 2002.

La Lucha por el pasado: Cómo construímos la memoria social. $1^{\mathrm{a}}$ ed Ciudad Autónoma de Buenos Aires: ISBN: 978-987-629-748-6. Siglo XXI Editores. Argentina, 2017.

Entrevista concedida a Carlos Artur Gallo. Cadernos do NUPPOME, Núcleo de Pesquisa sobre Políticas de Memória, UFPEL, ano 1, número 2, ISSN 2596-285X, pp. 5 12, agosto de 2019. Disponível em: https://wp.ufpel.edu.br/nuppome/2019/08/08/segundonumero-da-cadernos-do-nuppome-e-publicado/

PADRÓS, Enrique Serra. A ditadura civil-militar uruguaia doutrina e segurança nacional. VARIA HISTORIA, Belo Horizonte, vol.28, n o 48, p.495-517: jul/dez 2012.

ZAVERUCHA, Jorge. Relações civil-militares: o legado autoritário da constituição brasileira de 1988. In: TELES, Edson, SAFATLE, Vladimir. (orgs.). O que resta da ditadura: a exceção brasileira. São Paulo: Boitempo, p. 41-76, 2010. 